Research Article

\title{
Effect of Saline Water on Growth, Yield and Ions Content in Spinach Genotypes
}

\author{
Saleem Maseeh Bhatti ${ }^{*}$, Aslam Khan Gadehi ${ }^{1}$, Inayatullah Rajpar ${ }^{1}$, Muhammad Nawaz Kandhro ${ }^{2}$, \\ Mukesh Kumar Soothar ${ }^{1}$ and Zohaib Ur Rehman Bughio ${ }^{1}$
}

${ }^{1}$ Department of Soil Science, ${ }^{2}$ Department of Agronomy, Sindh Agriculture University Tandojam, Pakistan.

\begin{abstract}
A greenhouse experiment was executed to quantify the response of spinach (Spinacia oleracea L.) genotypes (English and Sindhi) against a range of $\mathrm{NaCl}$ salt-waters (EC 2.0, 4.0, 6.0 and $8.0 \mathrm{dS} \mathrm{m}^{-1}$ ) and canal water (EC $\left.0.3 \mathrm{dS} \mathrm{m}^{-1}\right)$. Spinach plants were irrigated with defined EC levels at $80 \%$ field capacity of a clay loam, non-saline soil. Results indicated that the growth and yield parameters of spinach genotypes were constantly decreased with an increase in $\mathrm{EC}$ levels of irrigation water. The plants irrigated with EC 6.0 and $8.0 \mathrm{dS} \mathrm{m}^{-1}$ had less fresh weight of leaves (> 30\%) than the plants that were irrigated with canal water. English spinach significantly produced more fresh weight of leaves $(20.86 \pm 0.50$ grams $)$ than Sindhi spinach $\left(18.82 \pm 0.27\right.$ grams). The concentration of $\mathrm{Na}^{+}$increased up to 3.4 times and $\mathrm{Cl}^{-}$concentration enhanced up to 2.7 times in leaves of spinach genotypes while no profound effects on $\mathrm{K}^{+}$concentration in leaves was observed. English spinach accumulated significantly more $\mathrm{Na}^{+}$and $\mathrm{Cl}^{-}$, and less $\mathrm{K}^{+}$than Sindhi spinach. In soil, the $\mathrm{EC}$, extractable $\mathrm{Na}^{+}$and soluble $\mathrm{Cl}^{-}$concentrations were greatly increased as a function of saline waters. Our findings suggest that the selected spinach genotypes may be irrigated with salt-water (up to $4 \mathrm{dS} \mathrm{m}^{-1}$ ) for an acceptable level of yield reduction $(\leq 27 \%)$, however more preference be given to English spinach in saline environment.

Received | October 11, 2020; Accepted | January 05, 2021; Published | March 30, 2021

*Correspondence | Saleem Maseeh Bhatti, Department of Soil Science, Sindh Agriculture University Tandojam, Pakistan; Email: smbhatti@ sau.edu.pk

Citation | Bhatti, S.M., Gadehi, A.K., Rajpar, I., Kandhro, M.N., Soothar, M.K. and Bughio, Z.R., 2021. Effect of saline water on growth, yield and ions content in spinach genotypes. Journal of Innovative Sciences, 7(1): 78-87.

DOI | http://dx.doi.org/10.17582/journal.jis/2021/7.1.78.87

Keywords | Salinity, Spinach, Growth, Yield, Ion contents
\end{abstract}

\section{Introduction}

$\mathrm{F}$ resh water resources of the world are declining because of natural and human activities. As a consequence, humans have to work on non-formal water supplies to meet its personal, agricultural and industrial uses (Qadir et al., 2007). Considerable evidence exists which describes that the farmers use saline groundwater and/or wastewater for crop cultivation in developing countries including Pakistan (Ghafoor et al., 1994; Kahlown and Azam, 2003; Bhatti et al., 2018). Saline water irrigation could have negative impacts on crops (reduction in growth and yield; Jamil et al., 2006; Sarker et al., 2014) and soils (increase in salts build up; Sharma et al., 1991; Ragab et al., 2008). However, extensive research indicates that the hostility of saltwater may be reduced with improved farming and proper management practices (Francois et al., 1994; Oron et al., 2002; Kahlown et al., 2003; Qadir and Oster, 2004; Bhatti et al., 2015). For efficient utilization of saline water, one choice includes the use of salt-tolerant crop species and cultivars and to irrigate them according to their tolerance level. Crop species and cultivars behave 
differently when they are exposed to salts (Hamdy et al., 1993; De Pascale and Barbieri, 1995; Minhas, 1996).

Little effort has been made where the impact of saline water on spinach crop (Spinacia oleracea L.) and potential salt-tolerant spinach cultivars are identified (Turhan et al., 2011, 2013). Spinach is an important Rabi vegetable crop which is rich in beta carotene, vitamin $\mathrm{A}, \mathrm{C}, \mathrm{E}$, and $\mathrm{K}$, calcium, magnesium, potassium, phosphorus, iron, sulphur, sodium, folicand oxalic acid, proteins, and secondary metabolites, e.g., 20-Hydroxyecdysone, which has antioxidant and tonic features (Dawn, 2006; Ferreira et al., 2018; Muchate et al., 2019). This crop is also preferred by farmers because of its high biomass in few months' time (Maftoun et al., 2005). However, research conducted for spinach indicates the contrasting results when the crop is cultivated in saline environment. The undesirable effects of salts on growth and yield parameters, physiological parameters, and imbalance of nutrients (mainly $\mathrm{K}^{+}, \mathrm{Na}^{+}$and $\mathrm{Cl}^{-}$) in spinach tissues was witnessed in many studies (Robinson et al. 1983; Turhan et al., 2011; Turhan et al., 2013; Xu and Mou, 2016). In a study, Keshavarzi et al. (2011) found spinach plants sensitive to salinity and advised that the crop should not be cultivated in saline soils. In contrast, recent studies report no significant loss in spinach yield and nutritional value with saline water levels up to $9 \mathrm{dS} \mathrm{m}^{-1}$ (Ors and Suarez, 2016; Ferreira et al., 2018). In another study, spinach yield was increased at EC levels of 4 and $7 \mathrm{dS} \mathrm{m}^{-1}$ and subsequently declined at EC $9.0 \mathrm{dS} \mathrm{m}^{-1}$ and above (Ors and Suarez, 2017). In a recent study, Ferreira $e t$ al. (2020) suggested the threshold level for spinach between 7 to $10 \mathrm{dS} \mathrm{m}^{-1}$ for water salinity, and from 5.6 to $8.9 \mathrm{dS} \mathrm{m}^{-1}$ for soil salinity. The difference in spinach behavior to salinity in these studies may be attributed to many factors including variable saltwater levels, soil $\mathrm{EC}$ values, growth media (laboratory, greenhouse, and nutrient culture), crop cultivars, harvesting time, climate, and soil physico-chemical characteristics. It becomes important in this scenario to conduct specific trials in the local conditions to provide a clear guideline to the poor farming community. Therefore, this study was carried out to determine the effect of saline irrigation water on growth, yield and ions content of existing spinach cultivars in Pakistan. To our knowledge, only one study is reported in Pakistan, whereby an effort was made to alleviate the effects of soil salinity in spinach by co-application of $\mathrm{K}$ fertilizer doses with PGPR species (Zafar-ul-Hye et al., 2020). The findings of current research will be helpful: (i) to describe the level of saline water that can be used to attain acceptable spinach yield, and (ii) to highlight the spinach cultivar that is tolerant to salinity.

\section{Materials and Methods}

A greenhouse experiment was executed with two spinach (Spinacia oleracea L.) genotypes (English spinach and Sindhi spinach, locally called) at the Department of Soil Science, Sindh Agriculture University Tandojam Pakistan. Arable soil (plough layer) from an agricultural farm at Nasarpur Tando Allahyar Pakistan was collected, air dried, sieved and placed in $5 \mathrm{~kg}$ plastic pots (length $24 \mathrm{~cm}$, diameter $20.5 \mathrm{~cm}$ ) with holes in the bottom. The pots were organized on a wooden bench in CRD (complete randomized design) with three replications of each treatment.

Five seeds of each spinach genotype were placed in pots at $4 \mathrm{~cm}$ distance. After emergence, one healthy plant was allowed to grow till maturity (Figure 1). The $\mathrm{N}, \mathrm{P}_{2} \mathrm{O}_{5}, \mathrm{~K}_{2} \mathrm{O}$ fertilizers were added to each pot at recommended rates of 75,75 and $50 \mathrm{~kg} \mathrm{ha}^{-1}$ respectively (Baloch, 2013). The saline waters of desired concentrations $\left(2,4,6\right.$, and $\left.8 \mathrm{dS} \mathrm{m}{ }^{-1}\right)$ were prepared by dissolving the calculated amount of $\mathrm{NaCl}$ salt (analytical grade) in the distilled water. Canal water having an EC of $0.3 \mathrm{dS} \mathrm{m}^{-1}$ was used as Control treatment. Canal water and/or saline waters were applied to each pot at $80 \%$ field capacity (FC) of the soil (Figure 2). At harvest, the agronomical parameters recorded for each spinach genotypes were: numbers of leaves per plant (only fully matured), and fresh and dry weight of leaves per plant.

\subsection{Analysis of plant samples for $\mathrm{K}^{+}, \mathrm{Na}^{+}$and $\mathrm{Cl}^{-}$}

When the spinach plants attained marketable size, the plants were harvested. Plants of each genotype from an individual pot were collected by cutting at the soil surface with sharp scissors (Figure 3). These plant samples were washed with running tap water, and distilled water. Plant samples were weighed for their fresh weight using digital weight balance. The samples were oven-dried at $70{ }^{\circ} \mathrm{C}$ for 48 hours, and were measured for their dry weight for leaves. Oven dried spinach leaves were ground using Blender and Grinder Machine (Anex Germany Products). The concentration of $\mathrm{K}^{+}$and $\mathrm{Na}^{+}$in plant tissues was 
determined by wet digestion method as outlined by Estefan et al. (2013). In brief, $0.5 \mathrm{~g}$ ground plant material was digested with $10 \mathrm{ml}$ of di-acids $\left(\mathrm{HNO}_{3}-\right.$ $\left.\mathrm{HClO}_{4}, 2: 1\right)$ using hotplate until the white fumes appeared. The samples were allowed to cool and were diluted with $50 \mathrm{ml}$ of distilled water. The concentration of $\mathrm{K}^{+}$and $\mathrm{Na}^{+}$was determined by Flame photometer. The concentration of chloride in plant tissues was determined by the procedure given by Ghosh and Drew (1991). In brief, $0.5 \mathrm{~g}$ plant samples were added with $10 \mathrm{ml}$ distilled water and added with $0.1 \mathrm{ml}$ of 1\% Tween 20. The samples were digested on hot plate and filtered. For titration, $5 \mathrm{ml}$ of filtrate was added with 5-6 drops of phenolphthalein indicator. The samples were titrated against $0.01 \mathrm{~N} \mathrm{AgNO} 3$ till the color shifted to reddish brown.

\subsection{Soil collection, processing, and analysis}

Soil samples were collected two times, before sowing of spinach plants and after their harvest. The samples were air dried in shade, crushed, passed through $2 \mathrm{~mm}$ stainless steel sieve and stored. Soil samples collected before sowing of spinach plants were analyzed for various physical and chemical parameters (texture, EC, $\mathrm{pH}$, organic matter content, and $\mathrm{K}^{+}, \mathrm{Na}^{+}$and $\mathrm{Cl}^{-}$ contents). The texture of soil samples was performed by Hydrometer method (Bouyoucos, 1962). The EC and $\mathrm{pH}$ were recorded in 1:2.5 soil water extracts, using digital $\mathrm{pH}$ and $\mathrm{EC}$ meters. Soil organic matter content was determined as proposed by Walkley and Black (1934). For extractable potassium and sodium determination, the Ammonium acetate method, outlined by Estefan et al. (2013), was adopted. Soluble chloride concentration in soil samples was determined by Mohr's titration method (Estefan et al., 2013).

After spinach harvest, the soil samples were collected from each pot of spinach genotypes at $0-15 \mathrm{~cm}$ depth by stainless steel auger (length: 1 feet and diameter: $3 \mathrm{~cm}$ ). The samples were processed and analyzed for the $\mathrm{EC}, \mathrm{K}^{+}, \mathrm{Na}^{+}$and $\mathrm{Cl}^{-}$ions by the methods outlined above.

\section{Results and Discussion}

\subsection{Physico-chemical characteristics of soil before sowing}

It was found that the experimental soil was clay loam, slightly alkaline in reaction $(7.50 \pm 0.04)$, non-saline $\left(0.74 \pm 0.04 \mathrm{dS} \mathrm{m}^{-1}\right)$, low in organic matter content $(0.53 \pm 0.03 \%)$ and high in extractable $\mathrm{K}^{+}$content $\left(267 \pm 33 \mathrm{mg} \mathrm{kg}^{-1}\right)$. The extractable $\mathrm{Na}^{+}$content in soil was $200 \pm 58 \mathrm{mg} \mathrm{kg}^{-1}$ and soluble $\mathrm{Cl}^{-}$was $0.03 \pm 0.002 \%$. The results of plant parameters are described by considering the effect of saline waters on an individual genotype. After wards, both genotypes are compared to find out their response as a function of saline waters.

\subsection{Effect of saline waters on plant growth and yield} parameters in spinach genotypes

A constant decrease in number of leaves plant ${ }^{-1}$, and fresh and dry weight of spinach plants was observed with an increase in EC levels of water in both spinach genotypes $(P<0.05$; Table 1$)$. With respect to control, the decrease for these parameters ranged from 8 to $59 \%$ in salt treatments. A significant decrease in these parameters was observed when spinach plants were irrigated with saltwater of $8.0 \mathrm{dS} \mathrm{m}^{-1}$ than the plants that received canal water and saltwater of $2.0 \mathrm{dS} \mathrm{m} \mathrm{m}^{-1}$. For both spinach genotypes, the plants irrigated with EC 6.0 and 8.0 had $>30 \%$ reduction in number of leaves, and fresh and dry weight of plants than the plants that were irrigated with canal water.

Spinach genotypes varied significantly only for fresh weight $(P<0.05)$ with respect to saline waters. The plants of English spinach had significantly more fresh weight (20.86 \pm 0.50 grams) than the plants of Sindhi spinach (18.82 \pm 0.27 grams).

\subsection{Effect of saline waters on $\mathrm{Na}^{+}, \mathrm{K}^{+}$and $\mathrm{Cl}^{-}$concentra- tions in spinach leaves}

There was a significant enhancement in $\mathrm{Na}^{+}$and $\mathrm{Cl}^{-}$ concentration while a non-significant decline in $\mathrm{K}^{+}$ concentration in spinach leaves with saline water applications (Table 2). The effect of salt-water having EC 6.0 and $8.0 \mathrm{dS} \mathrm{m}^{-1}$ was more profound whereby a significantly high $\mathrm{Na}^{+}$and $\mathrm{Cl}^{-}$concentration in spinach leaves of both genotypes was noticed than the plants that received salt-water of 0.3 and $2.0 \mathrm{dS}$ $\mathrm{m}^{-1}$. In both spinach genotypes, the plants that were watered with 2.0 to $8.0 \mathrm{dS} \mathrm{m}^{-1}$ had 1.4 to 3.4 times greater $\mathrm{Na}^{+}$concentration, and 1.1 to 2.7 times more $\mathrm{Cl}^{-}$concentration in leaves than the plants that were irrigated with canal water. In case of $\mathrm{K}$, there was 2.4 to $21 \%$ decrease in $\mathrm{K}^{+}$concentration in spinach leaves of both genotypes with respect to control treatment.

There was a noteworthy variation between Sindhi and English spinach for $\mathrm{Na}^{+}, \mathrm{Cl}^{-}$and $\mathrm{K}^{+}$concentrations in their leaves $(P<0.05)$. The plants of English spinach accumulated significantly more $\mathrm{Na}^{+}(2.11 \pm 0.16 \%)$ and $\mathrm{Cl}^{-}(1.08 \pm 0.01 \%)$ in their leaves than the plants 
of Sindhi spinach $\left(\mathrm{Na}^{+}: 1.43 \pm 0.18 \%\right.$, and $\mathrm{Cl}^{-}: 0.92$ $\pm 0.03 \%$ ). In case of $\mathrm{K}$, the plants of Sindhi spinach contained significantly more $\mathrm{K}^{+}(4.58 \pm 0.13 \%)$ in their leaves than the plants of English spinach (3.94 $\pm 0.21 \%)$.

3.4 Effect of saline waters on selected soil properties (EC, $\mathrm{Na}^{+}, \mathrm{K}^{+}$and $\mathrm{Cl}^{-}$concentrations) after harvest of spinach plants

The $\mathrm{EC}, \mathrm{Na}^{+}$and $\mathrm{Cl}^{-}$concentrations were increased while the $\mathrm{K}^{+}$concentration in soil was decreased with each unit increase in $\mathrm{EC}$ of irrigation water (Table 3). The maximum increase in $\mathrm{EC}, \mathrm{Na}^{+}$and $\mathrm{Cl}^{-}$values was witnessed where $8.0 \mathrm{dS} \mathrm{m}^{-1}$ was used (the increase was 2 to 3 times over control treatment). Similarly, the minimum values of $\mathrm{K}^{+}$were noted in the pots which were irrigated with EC of $8.0 \mathrm{dS} \mathrm{m}^{-1}$.

There was a notable difference in $\mathrm{EC}$ and $\mathrm{Cl}^{-}$build up in pots where spinach genotypes were grown. The pots where Sindhi spinach was grown had significantly higher EC $\left(2.48 \pm 0.01 \mathrm{dS} \mathrm{m}^{-1}\right)$ and soluble $\mathrm{Cl}^{-}(0.06 \pm 0.00 \%)$ values in soil than the pots where English spinach was grown (EC: $1.27 \pm 0.07 \mathrm{dS}$ $\left.\mathrm{m}^{-1} ; \mathrm{Cl}: 0.05 \pm 0.00 \%\right)$.

\subsection{Effect of saline waters on growth and yield parameters in spinach genotype}

The selected growth and yield parameters of spinach plants were decreased with increasing EC levels of saline water. The decline in growth and yield parameters in spinach genotypes may be attributed to many factors including (i) lowering of water potential by the salts (Flowers and Flowers, 2005), (ii) greater uptake of $\mathrm{Na}^{+}$and $\mathrm{Cl}^{-}$ions in plant leaves (Table 2), which eventually injure plant cells (Munns et al., 2006), (iii) imbalance in essential nutrients (e.g. K, $\mathrm{P}, \mathrm{Ca}$ and $\mathrm{NO}_{3}^{-}$) availability, uptake, transport, and partitioning in plants (Grattan and Grieve, 1999; Flowers and Flowers, 2005), and (iv) higher synthesis of stress ethylene (Zafar-ul-Hye et al., 2020). Negative impacts of salinity on spinach growth, yield and physiological attributes have been documented previously (Robinson et al., 1983; Turhan et al., 2013; $\mathrm{Xu}$ and Mou, 2016). In a greenhouse study on spinach (cv. Space), irrigated by a range of saline waters, the fresh and dry weights were decreased with increasing the salinity levels of saline waters (Suleiman et al., 2002). Ors and Suarez (2016) studied spinach (cv. Racoon) response under saline water treatments and reported that higher salinity decreased all gas exchange, and vegetative and yield parameters (shoot height, leaf area, and dry weight).

In our research study, EC 6.0 and $8.0 \mathrm{dS} \mathrm{m}^{-1}$ had the most adverse effect whereby greater than $25 \%$ reduction in growth and yield parameters was observed for spinach genotypes. This indicates that the selected spinach genotypes should not be grown with these saline water levels. The other researchers observed different results for unacceptable levels of saline water. For example, Sarker et al. (2014) noticed that at EC 8.0 and $16.0 \mathrm{dS} \mathrm{m}^{-1}$ more loss in germination and developmental traits of tested vegetable crops (radish, cabbage, mustard, and water spinach) was observed. In another study, Ors and Suarez (2016) conducted three set of trials on spinach with different EC levels of saline waters. It was reported that there was no significant loss in spinach yield for salt-water levels of $9 \mathrm{dS} \mathrm{m} \mathrm{m}^{-1}$, but EC 12.0 and $15.0 \mathrm{dS} \mathrm{m} \mathrm{m}^{-1}$ decreased all gas exchange (photosynthesis, transpiration rate, stomatal conductance, and chlorophyll content), vegetative and yield parameters (shoot height, leaf area, and dry weight) of spinach. The impact of $300 \mathrm{mM}$ was overwhelming on growth and water content in spinach than 100 and $200 \mathrm{mM} \mathrm{NaCl}$ (Muchate et al., 2019).

In our study, English spinach performed significantly well for yield (fresh weight) under saline water treatments when compared with Sindhi spinach. This difference in yield may be attributed to genetical variance. Difference in growth and yield parameters for various crops with spinach and among spinach genotypes in saline treatments has also been observed by other researchers (Speer and Kaiser, 1991; Yousif et al., 2010). In a study, Turhan et al. (2011) examined the effect of different $\mathrm{NaCl}$ concentrations ( 0 to $200 \mathrm{mM}$ ) on seeds of four spinach cultivars. The green gold cultivar performed best for most of the defined parameters in exposed salt levels. In a recent study, spinach cultivar Raccoon performed better in shoot biomass than cultivar Gazelle at higher $\mathrm{NaCl}$ concentrations (Ferreira et al., 2020).

\subsection{Effect of saline waters on ions $\left(\mathrm{Na}^{+}, \mathrm{K}^{+}\right.$and $\left.\mathrm{Cl}^{-}\right)$} concentration in spinach genotypes

The $\mathrm{Na}^{+}$and $\mathrm{Cl}^{-}$concentration in spinach leaves was greatly increased while the $\mathrm{K}^{+}$concentration was nonsignificantly decreased with increasing saline water treatments. The possible reason of high concentration of $\mathrm{Na}^{+}$and $\mathrm{Cl}^{-}$in spinach leaves was because of applications of $\mathrm{NaCl}$ enriched water in soil. The reason 
for decreased $\mathrm{K}^{+}$concentration in spinach leaves is the presence of $\mathrm{Na}^{+}$ions which are active competitors of $\mathrm{K}^{+}$in plant uptake mechanism (Grattan and Grieve, 1999). Nonetheless, recent study indicates that spinach plants favor $\mathrm{K}^{+}$accumulation over $\mathrm{Na}^{+}$, regardless of salinity levels of water (Ferreira et al., 2020). A non-significant effect of saline waters for $\mathrm{K}$ accumulation in spinach leaves in our study validates the findings of Ferreira et al. (2020). A rise in $\mathrm{Na}^{+}$ and $\mathrm{Cl}^{-}$concentrations and drop in $\mathrm{K}^{+}$concentration in spinach leaves is documented in salinity trials (Suleiman et al., 2002; Shimomachi et al., 2008; Turhan et al., 2013; Muchate et al., 2019).

Table 1: Effect of saline waters on the growth and yield parameters of spinach genotypes.

\begin{tabular}{|c|c|c|c|c|c|c|}
\hline \multirow{2}{*}{$\begin{array}{l}\text { Saline water } \\
\text { (EC levels) }\end{array}$} & \multicolumn{2}{|c|}{ Number of leaves plant ${ }^{-1}$} & \multicolumn{2}{|c|}{ Fresh weight plant $^{-1}(\mathrm{~g})$} & \multicolumn{2}{|c|}{ Dry weight plant $^{-1}(\mathrm{~g})$} \\
\hline & Sindhi & English & Sindhi & English & Sindhi & English \\
\hline $0.3^{\dagger}$ & $12.67 \pm 0.88^{a}$ & $13.00 \pm 1.00^{a}$ & $26.01 \pm 0.61^{\mathrm{a}}$ & $27.22 \pm 1.12^{a}$ & $4.37 \pm 0.60^{a}$ & $3.69 \pm 0.38^{a}$ \\
\hline 2.0 & $11.00 \pm 0.58 \mathrm{ab}$ & $11.33 \pm 0.88^{a b}$ & $22.30 \pm 1.31^{\mathrm{ab}}$ & $23.76 \pm 1.15^{a b}$ & $3.53 \pm 0.38^{\mathrm{ab}}$ & $3.38 \pm 0.28^{a}$ \\
\hline 4.0 & $9.17 \pm 0.44^{b}$ & $9.33 \pm 0.17 b c$ & $19.94 \pm 1.17^{b}$ & $19.97 \pm 1.20 \mathrm{bc}$ & $3.14 \pm 0.03 \mathrm{ab}$ & $2.68 \pm 0.28 \mathrm{ab}$ \\
\hline 6.0 & $8.17 \pm 0.60^{b c}$ & $8.83 \pm 0.88^{b c}$ & $15.08 \pm 1.12^{c}$ & $18.23 \pm 1.56^{b c}$ & $2.93 \pm 0.30^{\mathrm{ab}}$ & $2.52 \pm 0.08 \mathrm{ab}$ \\
\hline 8.0 & $5.17 \pm 0.67^{c}$ & $7.33 \pm 0.60^{c}$ & $10.76 \pm 0.79^{\mathrm{c}}$ & $15.14 \pm 1.08^{c}$ & $1.96 \pm 0.50^{\mathrm{b}}$ & $1.95 \pm 0.13^{b}$ \\
\hline Mean of genotypes & $9.23 \pm 0.39$ & $9.97 \pm 0.45$ & $18.82 \pm 0.27^{\mathrm{B}}$ & $20.86 \pm 0.50^{\mathrm{A}}$ & $3.19 \pm 0.27$ & $2.84 \pm 0.17$ \\
\hline
\end{tabular}

$\dagger$ EC of canal water; Each value is a mean \pm SE $(n=3)$; Means followed by different small letters in a column are significantly different from each other $(P<0.05)$ as a function of saline waters; Means followed by different capital letters down a row show significant difference between spinach genotypes $(P<0.05)$.

Table 2: Effect of saline waters on ions concentration $\left(\mathrm{Na}^{+}, \mathrm{K}^{+}\right.$and $\left.\mathrm{Cl}^{-}\right)$in spinach genotypes.

\begin{tabular}{|c|c|c|c|c|c|c|}
\hline \multirow{2}{*}{$\begin{array}{l}\text { Saline water } \\
\text { (EC levels) }\end{array}$} & \multicolumn{2}{|c|}{$\mathrm{Na}^{+}$concentration $(\%)$} & \multicolumn{2}{|c|}{$\mathrm{K}^{+}$concentration $(\%)$} & \multicolumn{2}{|c|}{$\mathrm{Cl}^{-}$concentration $(\%)$} \\
\hline & Sindhi & English & Sindhi & English & Sindhi & English \\
\hline $0.3^{\dagger}$ & $0.67 \pm 0.07^{c}$ & $1.20 \pm 0.12^{\mathrm{d}}$ & $5.07 \pm 0.27$ & $4.17 \pm 0.46$ & $0.53 \pm 0.08^{d}$ & $0.87 \pm 0.02^{d}$ \\
\hline 2.0 & $0.93 \pm 0.07 b c$ & $1.80 \pm 0.00^{c}$ & $4.77 \pm 0.19$ & $4.07 \pm 0.73$ & $0.78 \pm 0.01^{\mathrm{c}}$ & $0.96 \pm 0.05^{\mathrm{cd}}$ \\
\hline 4.0 & $1.13 \pm 0.07^{b}$ & $2.20 \pm 0.12 \mathrm{bc}$ & $4.67 \pm 0.15$ & $3.83 \pm 0.42$ & $0.89 \pm 0.01 b c$ & $1.10 \pm 0.03 b c$ \\
\hline 6.0 & $2.13 \pm 0.07^{a}$ & $2.40 \pm 0.12^{\mathrm{ab}}$ & $4.40 \pm 0.35$ & $3.87 \pm 0.13$ & $0.97 \pm 0.02^{b}$ & $1.18 \pm 0.03 \mathrm{ab}$ \\
\hline 8.0 & $2.27 \pm 0.13^{a}$ & $2.93 \pm 0.18^{a}$ & $4.00 \pm 0.21$ & $3.77 \pm 0.78$ & $1.41 \pm 0.01^{\mathrm{a}}$ & $1.31 \pm 0.04^{a}$ \\
\hline Mean of genotypes & $1.43 \pm 0.18^{\text {в }}$ & $2.11 \pm 0.16^{\mathrm{A}}$ & $4.58 \pm 0.13^{A}$ & $3.94 \pm 0.21^{\text {B }}$ & $0.92 \pm 0.03^{\text {в }}$ & $1.08 \pm 0.01^{\mathrm{A}}$ \\
\hline
\end{tabular}

$\dagger$ EC of canal water; Each value is a mean \pm SE $(n=3)$; Means followed by different small letters in a column are significantly different from each other $(P<0.05)$ as a function of saline waters; Means followed by different capital letters down a row show significant difference between spinach genotypes $(P<0.05)$.

Table 3: Effect of saline waters on $\mathrm{EC}$ and ions concentration $\left(\mathrm{Na}^{+}, \mathrm{K}^{+}\right.$and $\left.\mathrm{Cl}^{-}\right)$in soil after spinach harvest.

\begin{tabular}{|c|c|c|c|c|}
\hline \multirow{2}{*}{$\begin{array}{l}\text { Saline water } \\
\text { (EC levels) }\end{array}$} & \multicolumn{2}{|c|}{$\mathrm{EC}\left(\mathrm{dS} \mathrm{m}^{-1}\right)$} & \multicolumn{2}{|c|}{ Extractable $\mathrm{Na}^{+}$concentration $(\%)$} \\
\hline & Sindhi & English & Sindhi & English \\
\hline $0.3^{\dagger}$ & $1.13 \pm 0.03^{b}$ & $0.80 \pm 0.15^{b}$ & $0.25 \pm 0.01^{\mathrm{d}}$ & $0.24 \pm 0.02^{d}$ \\
\hline 2.0 & $2.30 \pm 0.55 \mathrm{ab}$ & $0.93 \pm 0.09^{b}$ & $0.33 \pm 0.01^{\mathrm{c}}$ & $0.32 \pm 0.01^{\mathrm{c}}$ \\
\hline 4.0 & $2.50 \pm 0.42 \mathrm{ab}$ & $1.03 \pm 0.23 b$ & $0.37 \pm 0.01 \mathrm{bc}$ & $0.37 \pm 0.01 \mathrm{bc}$ \\
\hline 6.0 & $2.83 \pm 0.23^{\mathrm{a}}$ & $1.57 \pm 0.07 \mathrm{ab}$ & $0.40 \pm 0.01^{b}$ & $0.41 \pm 0.01^{b}$ \\
\hline 8.0 & $3.63 \pm 0.12^{\mathrm{a}}$ & $2.03 \pm 0.33^{\mathrm{a}}$ & $0.51 \pm 0.02^{a}$ & $0.53 \pm 0.02^{a}$ \\
\hline Mean of genotypes & $2.48 \pm 0.01^{\mathrm{A}}$ & $1.27 \pm 0.07^{\mathrm{B}}$ & $0.37 \pm 0.01$ & $0.37 \pm 0.01$ \\
\hline Saline water (EC levels) & \multicolumn{2}{|c|}{ Extractable $\mathrm{K}^{+}$concentration $(\%)$} & \multicolumn{2}{|c|}{ Soluble $\mathrm{Cl}^{-}$concentration (\%) } \\
\hline 0.3 & $0.63 \pm 0.03$ & $0.61 \pm 0.02^{\mathrm{a}}$ & $0.03 \pm 0.005^{\mathrm{c}}$ & $0.03 \pm 0.002 e^{e}$ \\
\hline 2.0 & $0.57 \pm 0.04$ & $0.65 \pm 0.03{ }^{a}$ & $0.05 \pm 0.002^{b}$ & $0.04 \pm 0.001^{d}$ \\
\hline 4.0 & $0.54 \pm 0.03$ & $0.67 \pm 0.03^{a}$ & $0.06 \pm 0.002^{b}$ & $0.05 \pm 0.000^{c}$ \\
\hline 6.0 & $0.56 \pm 0.01$ & $0.71 \pm 0.04^{a}$ & $0.07 \pm 0.004^{b}$ & $0.06 \pm 0.000^{b}$ \\
\hline 8.0 & $0.63 \pm 0.01$ & $0.46 \pm 0.04^{b}$ & $0.10 \pm 0.004^{a}$ & $0.07 \pm 0.000^{a}$ \\
\hline Mean of genotypes & $0.59 \pm 0.01$ & $0.62 \pm 0.01$ & $0.06 \pm 0.00^{\mathrm{A}}$ & $0.05 \pm 0.00^{\text {в }}$ \\
\hline
\end{tabular}

$\dagger$ EC of canal water; Each value is a mean $\pm \mathrm{SE}(n=3)$; Means followed by different small letters in a column are significantly different from each other $(P<0.05)$ as a function of saline waters; Means followed by different capital letters down a row show significant difference between spinach genotypes $(P<0.05)$.

Journal of Innovative Sciences

June 2021 | Volume 7 | Issue 1 | Page 82 
In our research, the $\mathrm{Na}^{+}$and $\mathrm{Cl}^{-}$concentration in leaves of spinach genotypes was greatly increased at EC 6 and $8 \mathrm{dS} \mathrm{m}{ }^{-1}$. At these EC levels, the $\mathrm{Na}^{+}$ concentration in leaves ranged from 2.0 to 3.4 times and $\mathrm{Cl}^{-}$concentration ranged from 1.4 to 2.7 times superior than the control treatment. In a previous study, when five spinach cultivars were examined against four levels of $\mathrm{NaCl}$ (50,100, 150 and 200 $\mathrm{mM}$ ), the $\mathrm{Na}^{+}$and $\mathrm{Cl}^{-}$concentrations were massively increased and the $\mathrm{K}^{+}$concentration was greatly decreased at $150 \mathrm{mM}$ and $200 \mathrm{mM}$ (Turhan et al., 2013).

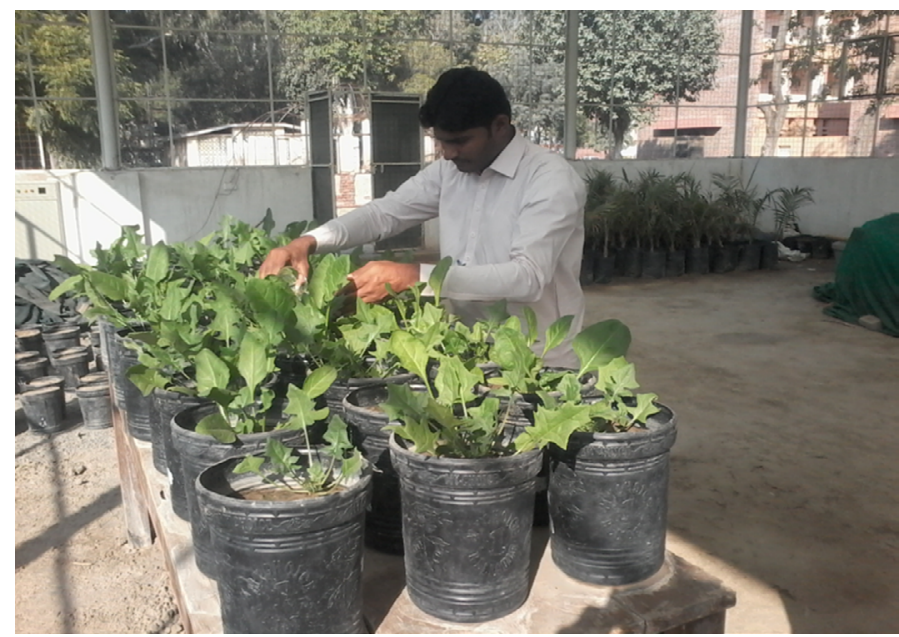

Figure 1: Thinning of spinach plants.

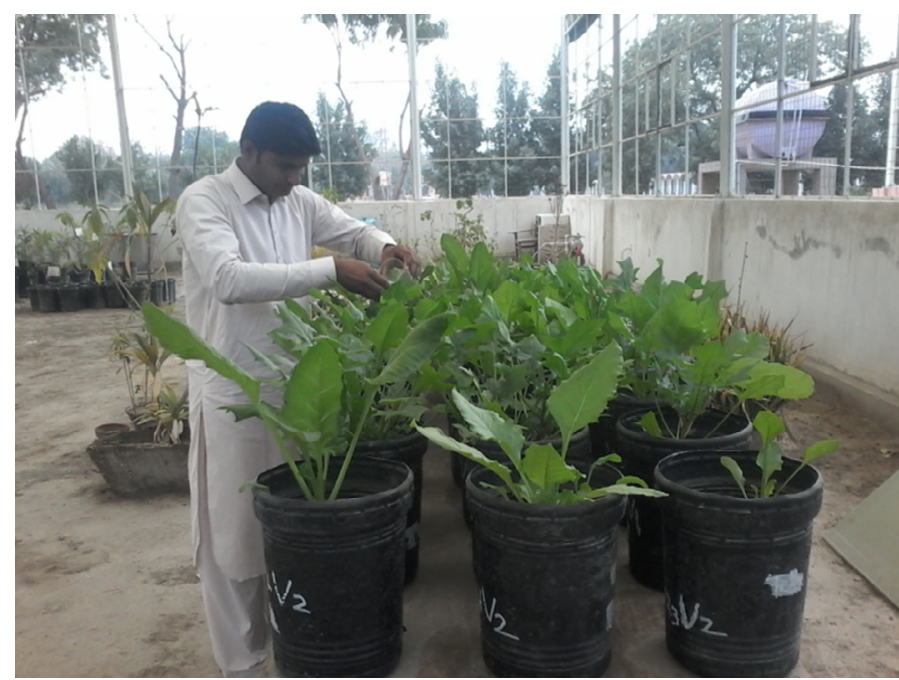

Figure 2: Irrigation of spinach plants.

In current study, English spinach accumulated significantly more $\mathrm{Na}^{+}$and $\mathrm{Cl}^{-}$and less $\mathrm{K}^{+}$in its leaves than the Sindhi spinach. The possible reason for this difference may be because of different genetic makeup and mechanism for mineral uptake in selected genotypes in saline environments. This difference of ions concentration further indicates that English spinach is more tolerant, as it is not massively reducing its fresh weight yield (Table 1) despite having high values of $\mathrm{Na}^{+}$and $\mathrm{Cl}^{-}$ions in its leaves. The other scientists obtained similar results of difference in ions concentration in selected plant species. Speer and Kaiser (1991) compared the ability of spinach (Spinacia oleracea L.) and peas (Pisum sativum) for extra and intracellular compartmentation in leaves under mild salinity conditions. They found that the $\mathrm{Na}^{+}$and $\mathrm{Cl}^{-}$accumulation in leaflets of peas was superior in comparison to the leaflets of spinach. Yousif et al. (2010) investigated the disparity in the salt uptake mechanisms between New Zealand spinach and water spinach at $\mathrm{NaCl}$ waters and reported the high concentration of $\mathrm{Na}^{+}$in the leaves of $\mathrm{New}$ Zealand spinach.

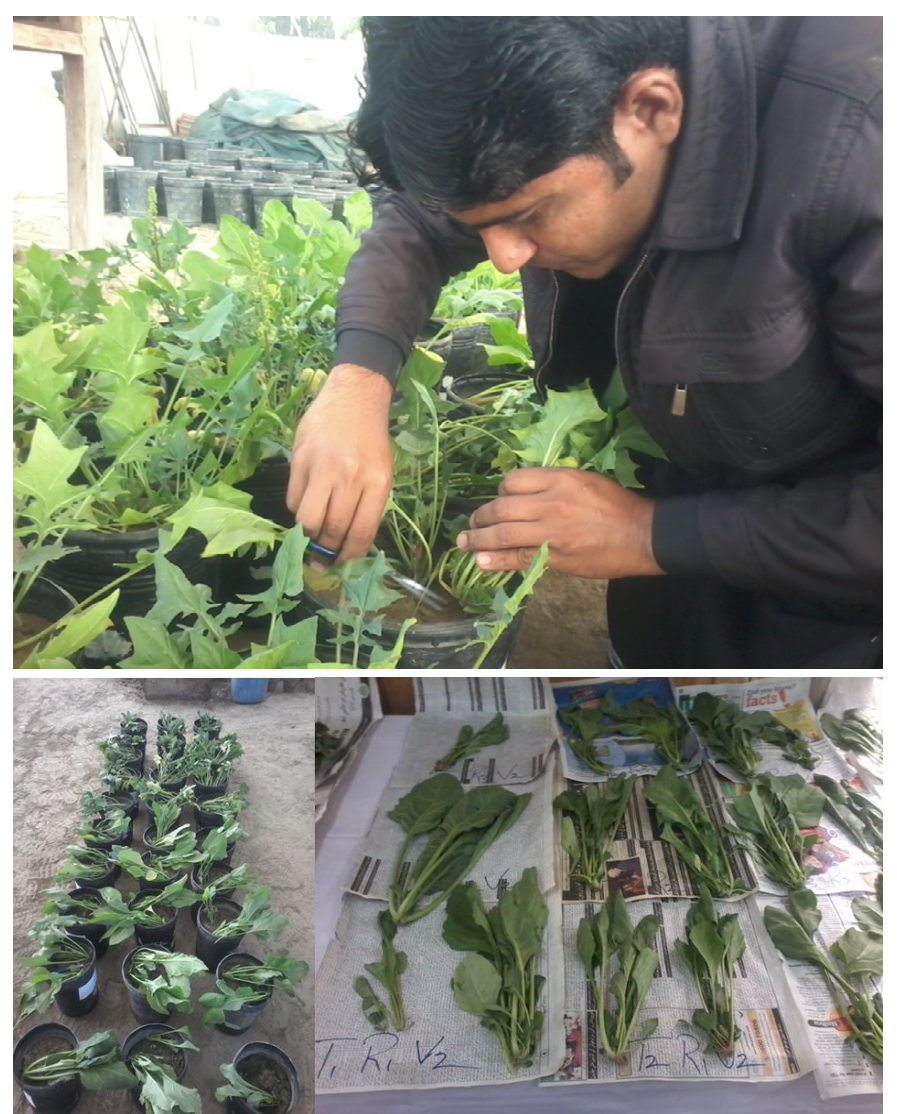

Figure 3: Harvest of spinach plants.

3.7 Effect of saline waters on soil parameters ( $E C, p H$, $\mathrm{Na}^{+}, \mathrm{K}^{+}$and $\mathrm{Cl}^{-}$) after harvest of spinach plants

In soil, the $\mathrm{EC}, \mathrm{Na}^{+}$and $\mathrm{Cl}^{-}$values were increased with rising salt-water levels, but $\mathrm{K}^{+}$concentration in soil was decreased with an increase in EC levels of saline waters. The reason for increasing $\mathrm{EC}$ and ions $\left(\mathrm{Na}^{+}\right.$and $\left.\mathrm{Cl}^{-}\right)$values in soil may be associated to the application of $\mathrm{NaCl}$ enriched saline water. Similar outcomes have been conveyed by other researchers. 
Bhatti (2004) conducted a wire-house experiment on wheat under saline water levels and reported that EC, $\mathrm{Na}^{+}$and $\mathrm{Cl}^{-}$values in soil were massively increased with increasing the saline water levels; however, the $\mathrm{K}^{+}$concentrations in soil were decreased. Ragab et al. (2008) found similar results; the $\mathrm{EC}, \mathrm{Na}^{+}$and $\mathrm{Cl}^{-}$ contents in soil were significantly increased while $\mathrm{K}^{+}$ and $\mathrm{pH}$ concentration were decreased in soil. Sharma et al. (1991) observed high values for $\mathrm{EC}, \mathrm{Na}^{+}$and $\mathrm{Cl}^{-}$ in soil with saline water applications.

\section{Conclusions and Recommendations}

The growth and yield parameters (number of leaves, and fresh and dry weight) of spinach genotypes were significantly decreased with increasing the EC levels of saline water. The plants irrigated with EC 6.0 and $8.0 \mathrm{dS} \mathrm{m} \mathrm{m}^{-1}$ had less fresh and dry weight of leaves. In spinach leaves, the $\mathrm{Na}^{+}$and $\mathrm{Cl}^{-}$concentrations were greatly increased while the $\mathrm{K}^{+}$concentration was decreased with increase in levels of $\mathrm{NaCl}$ salts. In both genotypes, English spinach produced greater fresh weight despite accumulating greater concentration of $\mathrm{Na}^{+}$and $\mathrm{Cl}^{-}$ions in its leaves than the Sindhi spinach. In soil, with the application of saline water, the EC, $\mathrm{Na}^{+}$, and $\mathrm{Cl}^{-}$values were augmented while the $\mathrm{K}^{+}$ concentration was decreased as a function of saline waters. Hence we suggest that the spinach genotypes (English and Sindhi) may be irrigated with salt-water having EC levels up to $4 \mathrm{dS} \mathrm{m}{ }^{-1}$ with an acceptable level of fresh weight reduction $(\leq 27 \%)$. English spinach appears relatively more tolerant to selected saline water levels than Sindhi spinach.

\section{Acknowledgments}

The data presented in this manuscript is a component of $\mathrm{MSc}$ Thesis, submitted to Sindh Agriculture University Tando Jam by second author (Aslam Khan Gadehi), and orally presented in two International Conferences in Pakistan.

\section{Source of funding}

This research didn't receive specific grant from any funding agency in the public, commercial or not-forprofit sectors.

\section{Key message}

Identification of salt tolerance level of a specific crop/ cultivar is important for saline water management. We suggest that the salt-water level to $4 \mathrm{dS} \mathrm{m} \mathrm{m}^{-1}$ may be used for selected spinach genotypes with an acceptable level of yield reduction.

\section{Novelty Statement}

We report first time in Pakistan about the variability between Spinach genotypes as a function of saline water, and recommend an acceptable saline irrigation water level for Spinach cultivation.

\section{Authors Contribution}

Saleem Maseeh Bhatti: Planned, supervised and helped in write up of the manuscript.

Aslam Khan Gadahi: Executed the experiment, write up of the manuscript.

Inayatullah Rajpar and Muhammad Nawaz Kandhro: Co-supervisors who provided technical assistance in experiment and write up.

Mukesh Kumar Soothar: Helped in laboratory analysis and data compilation.

Zohaib ur Rehman Bughio: Helped in latest reviews and journal formatting.

\section{Conflict of interest}

The authors have declared no conflict of interest.

\section{References}

Baloch, A.A., 2013. Evaluation of growth and yield performance of spinach in response to different fertility regimes. MSc. thesis, Department of Horticulture, Sindh Agriculture University Tandojam.

Bouyoucos, G.J., 1962. Hydrometer method improved for making particle size analyses of soils. Agronomy Journal, 1962; 54 (5): 464-465. https://doi.org/10.2134/agronj1962.00021962 005400050028x

Bhatti, S.M., 2004. Saline irrigation water effects at different growth stages, ion uptake and yield of wheat. MSc. thesis, Department Soil Science, Sindh Agriculture University Tandojam.

Bhatti, S.M., Rajpar, I. and Sial, N.B., 2015. Saline water application at various growth stages of wheat: Effect on growth, yield and yield components. Pakistan Journal of Agriculture, Agricultural Engineering and Veterinary Sciences, 31(2): 171-182.

Bhatti, S.M., Subhopoto, M., Saleem, M., Soothar, M., Depar, N., Tagar, A.A. and Hina, K., 2018. 
Cobalt concentration in rice cultivars and soil irrigated with untreated wastewater. Sindh University Research Journal-SURJ (Science Series) 50(2): 221-226.

Dawn, 2006. Venturing in spinach cultivation. Published in Dec. 11, 2006. http://www.dawn. $\mathrm{com} /$ news/222772/venturing-in-spinachcultivation.

De Pascale, S. and Barbieri, G., 1995. Effects of soil salinity from long-term irrigation with saline-sodic water on yield and quality of winter vegetable crops. Scientia Horticulturae, 64(3): 145-157. https://doi.org/10.1016/03044238(95)00823-3

Estefan, G., Sommer, R. and Ryan, J., 2013. Methods of soil, plant, and water analysis. A manual for the West Asia and North Africa region. ICARDA. Third Ed.

Ferreira, J.F.S., Sandhu, D., Liu, X. and Halvorson, J.J.,2018.Spinach (Spinaceaoleracea L.) Response to Salinity: Nutritional Value, Physiological Parameters, Antioxidant Capacity, and Gene Expression. Agriculture, 8(10): 163. https://doi. org/10.3390/agriculture8100163

Ferreira, J.F.S., Da Silva Filho, J.B., Liu, X. and Sandhu, D., 2020. Spinach plants favor the absorption of $\mathrm{K}^{+}$over $\mathrm{Na}^{+}$regardless of salinity, and may benefit from $\mathrm{Na}^{+}$When $\mathrm{K}^{+}$is deficient in the soil. Plants, 9(4): 507-512. https://doi. org/10.3390/plants 9040507

Flowers, T.J. and Flowers, S.A., 2005. Why does salinity pose such a difficult problem for plant breeders? Agricultural Water Management, 78(1-2): 15-24. https://doi.org/10.1016/j. agwat.2005.04.015

Francois, L.E., Grieve, C.M., Maas, E.V. and Lesch, S.M., 1994. Time of salt stress affects growth and yield components of irrigated wheat. Agronomy Journal, 86(1): 100-107. https://doi. org/10.2134/agronj1994.00021962008600010 $019 \mathrm{x}$

Ghafoor, A., Rauf, A., Arif, M. and Muzaffar, W., 1994. Chemical composition of effluents from different industries of the Faisalabad city. Pak. J. Agric. Sci., 31(4): 367-370.

Ghosh, G. and Drew, M.C., 1991. Comparison of analytical methods for extraction of chloride from plant tissue using $36 \mathrm{Cl}$ as tracer. Plant and Soil, 136(2): 265-268. https://doi.org/10.1007/ BF02150058

Grattan, S.R. and Grieve, C.M., 1999. Salinity mineral nutrient relations in horticultural crops. Scientia Horticulturae, 78(1-4): 127-157. https:// doi.org/10.1016/S0304-4238(98)00192-7

Hamdy, A., Abdel-Dayem, S. and Abu-Zeid, M., 1993. Saline water management for optimum crop production. Agricultural Water Management, 24(3): 189-203. https://doi.org/10.1016/03783774(93)90023-4

Jamil, M., Lee, D.B., Jung, K.Y., Ashraf, M., Lee, S.C. and Rha E.S., 2006. Effect of salt $(\mathrm{NaCl})$ stress on germination and early seedling growth of four vegetables species. Journal of Central European Agriculture, 7(2): 273-282.

Kahlown, M.A., Ashraf, M. and Yasin, M., 2003. Water management for efficient use of irrigation water and optimum crop production (Research Report-3). Pakistan Council of Research in Water Resources, Islamabad, Pakistan.

Kahlown, M.A. and Azam, M., 2003. Effect of saline drainage effluent on soil health and crop yield. Agricultural Water Management, 62(2): 127-138. https://doi.org/10.1016/S03783774(03)00096-9

Keshavarzi, M.H.B., Rafsanjani, M.O., Moussavinik, S.M. and Abdin, M.Z., 2011. Effect of salt $(\mathrm{NaCl})$ stress on germination and early seedling growth of Spinach (Spinacia oleracea L.). Annals of Biological Research, 2(4): 490-497.

Maftoun, M., Moshiri, F., Karimian, N. and Ronaghi, A.M., 2005. Effects of two organic wastes in combination with phosphorus on growth and chemical composition of spinach and soil properties. Journal of Plant Nutrition, 27(9): 1635-1651. https://doi.org/10.1081/ PLN-200026005

Minhas, P.S., 1996. Saline water management for irrigation in India. Agricultural Water Management, 30(1): 1-24. https://doi. org/10.1016/0378-3774(95)01211-7

Muchate, N.S., Rajurkar, N.S., Suprasanna, P. and Nikam, T.D., 2019. $\mathrm{NaCl}$ induced salt adaptive changes and enhanced accumulation of 20-hydroxyecdysone in the in vitro shoot cultures of Spinacia oleracea (L.). Scientific Reports, 9(1): 1-10. https://doi.org/10.1038/ s41598-019-48737-6

Munns, R., James, R.A. and Läuchli, A., 2006. Approaches to increasing the salt tolerance of wheat and other cereals. Journal of Experimental Botany, 57(5): 1025-1043. https://doi. 
org/10.1093/jxb/erj100

Oron, G., DeMalach, Y., Gillerman, L., David, I. and Lurie, S., 2002. SW soil and water: Effect of water salinity and irrigation technology on yield and quality of pears. Biosystems Engineering, 81(2): 237-247.

Ors, S. and Suarez, D.L., 2016. Salt tolerance of spinach as related to seasonal climate. Horticultural Science, 43(1): 33-41. https://doi. org/10.17221/114/2015-HORTSCI

Ors, S. and Suarez, D.L., 2017. Spinach biomass yield and physiological response to interactive salinity and water stress. Agricultural Water Management, 190: 31-41. https://doi. org/10.1016/j.agwat.2017.05.003

Qadir, M., Sharma, B.R., Bruggeman, A., Choukr-Allah, R. and Karajeh, F., 2007. Nonconventional water resources and opportunities for water augmentation to achieve food security in water scarce countries. Agricultural Water Management, 87(1): 2-22. https://doi. org/10.1016/j.agwat.2006.03.018

Qadir,M. and Oster,J.D., 2004. Crop and irrigation management strategies for saline-sodic soils and waters aimed at environmentally sustainable agriculture. Science of the Total Environment, 323(1-3): 1-19. https://doi.org/10.1016/j. scitotenv.2003.10.012

Ragab, A.A.M., Hellal, F.A. and Abd El-Hady, M., 2008. Water salinity impacts on some soil properties and nutrients uptake by wheat plants in sandy and calcareous soil. Australian Journal of Basic and Applied Sciences, 2(2): 225-233.

Robinson, S.P., Downton, W.J.S., Millhouse, J.A., 1983. Photosynthesis and ion content of leaves and isolated chloroplasts of salt-stressed spinach. Plant Physiology, 73(2): 238-242. https://doi.org/10.1104/pp.73.2.238

Sarker, A., Hossain, M.I. and Kashem, M.A., 2014. Salinity $(\mathrm{NaCl})$ tolerance of four vegetable crops during germination and early seedling growth. International Journal of Latest Research in Science and Technology, 3(1): 91-95.

Sharma, D.P., Singh, K.N., Rao, K.V.G.K. and Kumbhare, P.S., 1991. Irrigation of wheat with saline drainage water on a sandy loam soil. Agricultural Water Management, 19(3): 223-233. https://doi.org/10.1016/03783774(91)90043-I

Shimomachi, T., Kawahara, Y., Kobashigawa, C., Omoda, E., Hamabe, K. and Tamaya, K., 2008.
Effect of residual salinity on spinach growth and nutrient contents in polder soil. International Workshop on Greenhouse Environmental Control and Crop Production in Semi-Arid Regions 797. pp. 419-424. https://doi.org/10.17660/ ActaHortic.2008.797.60

Speer, M. and Kaiser, W.M., 1991. Ion relations of symplastic and apoplastic space in leaves from Spinacia oleracea L. and Pisum sativum L. under salinity. Plant Physiology, 97(3): 990-997. https://doi.org/10.1104/pp.97.3.990

Suleiman, S., Wilson, C. and Grieve, C.M., 2002. Effect of salinity and exogenously applied polyamines on growth and ion relations in spinach. Journal of Plant Nutrition, 25(12): 2705-2717. https://doi.org/10.1081/PLN120015533

Turhan, A., Kuscu, H., Ozmen, N., Asik, B.B., Serbeci, M.S. and Seniz, V., 2013. Alleviation of deleterious effects of salt stress by applications of supplementary potassium calcium on spinach. Acta Agriculturae Scandinavica, Section B Soil and Plant Science, 63(2): 184-192. https:// doi.org/10.1080/09064710.2012.736531

Turhan, A., Kuşçu, H. and Şeniz, V., 2011. Effects of different salt concentrations $(\mathrm{NaCl})$ on germination of some spinach cultivars. Journal of Agricultural Faculty of Uludag University, 25(1): 65-77.

Walkley, A. and Black, I.A., 1934. An examination of the Degtjareff method for determining soil organic matter, and a proposed modification of the chromic acid titration method. Soil Science, 37(1): 29-38. https://doi. org/10.1097/00010694-193401000-00003

$\mathrm{Xu}, \mathrm{C}$. and Mou, B., 2016. Responses of spinach to salinity and nutrient deficiency in growth, physiology, and nutritional value. Journal of the American Society for Horticultural Science, 141(1): 12-21. https://doi.org/10.21273/ JASHS.141.1.12

Yousif, B.S., Nguyen, N.T., Fukuda, Y., Hakata, H., Okamoto, Y., Masaoka, Y. and Saneoka, H., 2010. Effect of salinity on growth, mineral composition, photosynthesis and water relations of two vegetable crops; New Zealand spinach (Tetragonia tetragonioides) and water spinach (Ipomoea aquatica). International Journal of Agriculture and Biology, 12(2): 211-216.

Zafar-ul-Hye, M., Mahmood, F., Danish, S., Hussain, S., Gul, M., Yaseen, R. and Shaaban, 
M., 2020. Evaluating efficacy of plant growth promoting rhizobacteria and potassium fertilizer on spinach growth under salt stress. Pakistan Journal of Botany, 52(4): 1-7. https:// doi.org/10.30848/PJB2020-4(7) 